\title{
Cu nanoparticles supported on graphitic carbon nitride as an efficient electrocatalyst for oxygen reduction reaction
}

\author{
Henan Li a,c, Yanan Xua , Hansinee Sitinamaluwa a, Kimal Wasalathilakea, Dilini Galpaya ${ }^{\text {, }}$ \\ Cheng Yan ${ }^{\mathrm{a}, *}$ \\ a School of Chemistry, Physics and Mechanical Engineering, Queensland University of Technology (QUT), Brisbane 4001, Queensland, Australia \\ ${ }^{\mathrm{b}}$ Central Analytical Research Facility, Queensland University of Technology (QUT), Brisbane 4001, Queensland, Australia \\ c School of Chemistry and Chemical Engineering, Jiangsu University, Zhenjiang 212013, Jiangsu, China
}

\section{A R T I C L E I N F O}

\section{Article history:}

Received 30 November 2016

Accepted 31 December 2016

Published 5 June 2017

\section{Keywords:}

Oxygen reduction reaction

Graphitic carbon nitride

Nanoparticle

Electrocatalyst

Ionic liquid

\begin{abstract}
A B S T R A C T
High active and cost-effective electrocatalysts for the oxygen reduction reaction (ORR) are essential components of renewable energy technologies, such as fuel cells and metal/air batteries. Herein, we propose that ORR active $\mathrm{Cu} / \mathrm{graphitic}$ carbon nitride $(\mathrm{Cu} / \mathrm{g}-\mathrm{CN})$ electrocatalyst can be prepared via a facile hydrothermal reaction in the present of the ionic liquid (IL) bis(1-hexadecyl-3-methylimidazolium) tetrachlorocuprate $\left[\left(\mathrm{C}_{16} \mathrm{mim}\right)_{2} \mathrm{CuCl}_{4}\right]$ and protonated g-CN. The as-prepared $\mathrm{Cu} / \mathrm{g}-\mathrm{CN}$ showed an impressive ORR catalytic activity that a $99 \mathrm{mV}$ positive shift of the onset potential and 2 times kinetic current density can be clearly observed, comparing with the pure g-CN. In addition, the $\mathrm{Cu} / \mathrm{g}-\mathrm{CN}$ revealed better stability and methanol tolerance than commercial Pt/C (HiSPECTM $3000,20 \%$ ). Therefore, the proposed $\mathrm{Cu} / \mathrm{g}-\mathrm{CN}$, as the inexpensive and efficient ORR electrocatalyst, would be a potential candidate for application in fuel cells.
\end{abstract}

(C) 2017, Dalian Institute of Chemical Physics, Chinese Academy of Sciences. Published by Elsevier B.V. All rights reserved.
The crucial oxygen reduction reaction (ORR), one of the most process in metal-air batteries and fuel cells, is kinetically sluggish and requires a high over-potential, thus similarly, appeals for a highly efficient catalyst [1-3]. Up to now, platinum(Pt)-based materials are still the most popular ORR electrocatalysts with high current density and four-electron pathway, yet suffer remarkably from the high cost, low abundance, poor stability, methanol poisoning [4]. As a result, developments of alternative non-precious ORR electrocatalysts are of great important research area [5]. Nitrogen-modified carbon materials have been extensively investigated as heteroatom-modified carbon electrocatalysts for the ORR recently, which essentially comprise nitrogen incorporated, either at the edges or within the core structure of the carbon material by substituting one of the $s p^{2}$-hybridized carbon atoms in the graphitic structure [6-8]. They exhibited competitive electrocatalytic activity for ORR, thanks to doped nitrogen atom, especially the pyridinic or/and graphitic nitrogen in these carbon structure, that can boost the initial chemical adsorption of oxygen on the catalyst surface and also offer possible active sites for oxygen reduction [9-11]. Graphitic-phase carbon nitride (g-CN), a graphite-like carbonaceous material that is enriched with a very high nitrogen content including both pyridinic and graphitic nitrogen moieties, may act as a potential high efficient electrocalaysts for ORR. However, the g-CN with high nitrogen content has one disadvantage that the low electrical conductivity of g-CN strongly restricts the electron transport during the ORR process and also reduces its electrocatalytic activity

\footnotetext{
* Corresponding author. Tel: +61-7-31386630; E-mail: c2.yan@qut.edu.au This work was supported by the Australian Research Council Discovery Project (DP150101717).

DOI: 10.1016/S1872-2067(17)62764-5 | http://www.sciencedirect.com/science/journal/18722067 | Chin. J. Catal., Vol. 38, No. 6, June 2017
} 
[11-13]. Therefore, the development of high efficient ORR electrocalaysts based g-CN is still a significant challenge.

Herein, we report that a non-precious $\mathrm{Cu} / \mathrm{g}-\mathrm{CN}$ with a good electrocatalytic ORR performance could be prepared from a protonated g-CN and ionic liquid (IL) bis(1-hexadecyl-3-methylimidazolium) tetrachlorocuprate $\left[\left(\mathrm{C}_{16} \mathrm{mim}\right)_{2} \mathrm{CuCl}_{4}\right]$ in a hydrothermal way. Cooperating with transition metals $\mathrm{Cu}$ can supply some new electrocatalytic active sites and improve the conductivity of electrocatalyst. As non-precious electrocatalyst, $\mathrm{Cu} / \mathrm{g}$-CN showed much better long-term durability and methanol tolerance that the commercial Pt/C (HiSPEC тм 3000, $20 \%$ ) in an alkaline medium.

The protonated $\mathrm{g}-\mathrm{C}_{3} \mathrm{~N}_{4}$ and $\left(\mathrm{C}_{16} \mathrm{mim}\right)_{2} \mathrm{CuCl}_{4}$ were prepared according to our previous works $[14,15]$. For the $\mathrm{Cu} / \mathrm{g}-\mathrm{CN}$, $\left(\mathrm{C}_{16} \mathrm{mim}\right)_{2} \mathrm{CuCl}_{4}(1.3127 \mathrm{~g})$ was dissolved in ethylene glycol (EG) solvent $(20 \mathrm{~mL})$ to form a homogeneous solution. Then, the protonated g-CN $(0.0254 \mathrm{~g})$ and aqueous $\mathrm{NaOH}(1.28 \mathrm{~mL}, 5$ $\mathrm{mol} / \mathrm{L}$ ) were added into the above solution with vigorous stirring, respectively. After that the precursor was transferred to a Teflon-lined autoclave $(25 \mathrm{~mL})$ and heated at $160{ }^{\circ} \mathrm{C}$ for $48 \mathrm{~h}$. Lastly, $\mathrm{Cu} / \mathrm{g}$-CN was obtained by washing the precipitate with water and ethanol.

All the electrochemical measurements were performed on a CHI700 electrochemical workstation ( $\mathrm{CH}$ Instruments, China) and rotating ring disk electrode (RDE) (RRDE-3A, Japan) in a typical three-electrode cell equipped with gas flow systems. A RDE was used as the working electrode. $20 \mu \mathrm{L}$ of the electrocatalysts suspension in ethanol $(1 \mathrm{mg} / \mathrm{mL}$ of $\mathrm{Cu} / \mathrm{g}-\mathrm{CN}$ or 0.5 $\mathrm{mg} / \mathrm{mL}$ of commercial $\mathrm{Pt} / \mathrm{C}$ ) was drop-casted on the surface of the RDE. The electrode was allowed to dry at room temperature and heated at $60^{\circ} \mathrm{C}$ for $15 \mathrm{~min}$. After that, $5 \mu \mathrm{L}$ of $0.05 \mathrm{wt} \%$ Nafion was further drop-casted on the surface of the electrode. Finally, the electrode was again dried at room temperature and heated at $60{ }^{\circ} \mathrm{C}$ for $15 \mathrm{~min}$. A platinum filament and $\mathrm{Ag} / \mathrm{AgCl}(3$ $\mathrm{mol} / \mathrm{L} \mathrm{KCl}$ ) were used as counter and reference electrode, respectively. The electrolyte was $0.1 \mathrm{~mol} / \mathrm{L} \mathrm{KOH}$ in water, which was bubbled with $\mathrm{O}_{2}$ or $\mathrm{N}_{2}$ for 30 min and maintained with the same atmosphere during the measurements.

To achieve more textural information of $\mathrm{Cu} / \mathrm{g}-\mathrm{CN}, \mathrm{X}$-ray powder diffraction (XRD) measurements were performed (Fig. $1(\mathrm{a})$ ). It was found that both XRD patterns of g-CN and $\mathrm{Cu} / \mathrm{g}-\mathrm{CN}$ were dominated by a strong peak at $27.6^{\circ}$, almost the same as the typical interlayer-stacking peak (002) facet, indicating that $\mathrm{Cu} / \mathrm{g}-\mathrm{CN}$ remains the layered structure of the g-CN [16]. The typical face-centered cubic copper can be observed from the XRD pattern of Cu/g-CN (JCPDS card NO. 040836, $\alpha=0.3615$ $\mathrm{nm})$. No characteristic peaks of any other phases or impurities can be detected, confirming that the $\mathrm{Cu} / \mathrm{g}$-CN only contains $\mathrm{Cu}$ and g-CN. In the FT-IR spectrum of g-CN (Fig. 2(b)), the peaks at 1637 and $1243 \mathrm{~cm}^{-1}$ were attributed to the $\mathrm{C}=\mathrm{N}$ and $\mathrm{C}-\mathrm{N}$ stretching vibration modes, respectively [16]. The peak around $808 \mathrm{~cm}^{-1}$ corresponded to the s-triazine ring mode [17]. Moreover, in the FT-IR spectrum of $\mathrm{Cu} / \mathrm{g}$ - $\mathrm{CN}$, all the main characteristic peaks of g-CN can be clearly observed, indicating that the structure of g-CN in the composite does not change (Fig. 2(b)). Pure g-CN showed a two-dimensional sheet-like structure (Fig. 1(c)). Some black colored dots corresponding to the $\mathrm{Cu}$ nanoparticles were uniformly distributed on the surface of g-CN.
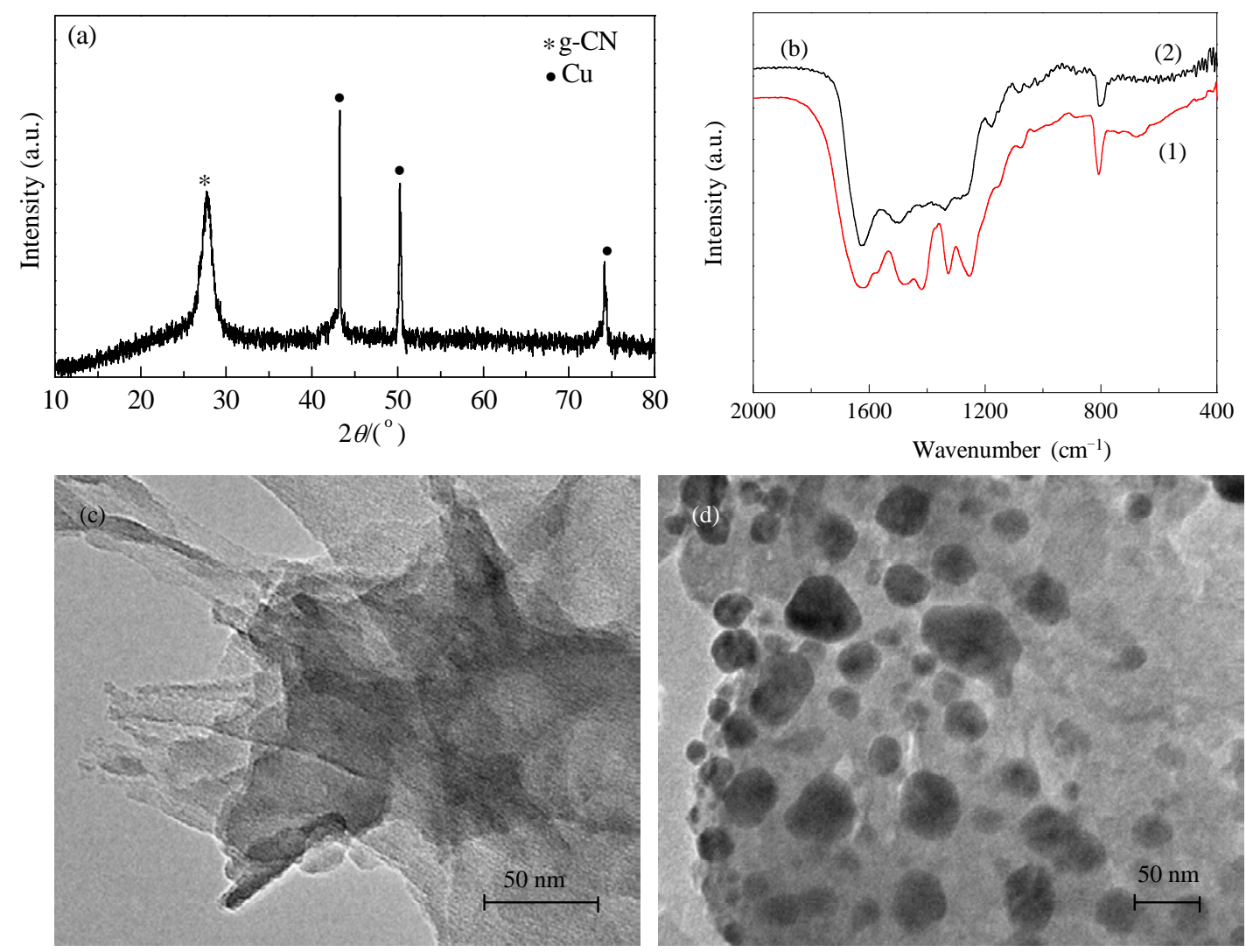

Fig. 1. (a) XRD pattern of Cu/g-CN; (b) FT-IR spectra of g-CN (1) and Cu/g-CN (2); TEM images of (c) g-CN and (d) Cu/g-CN, respectively. 

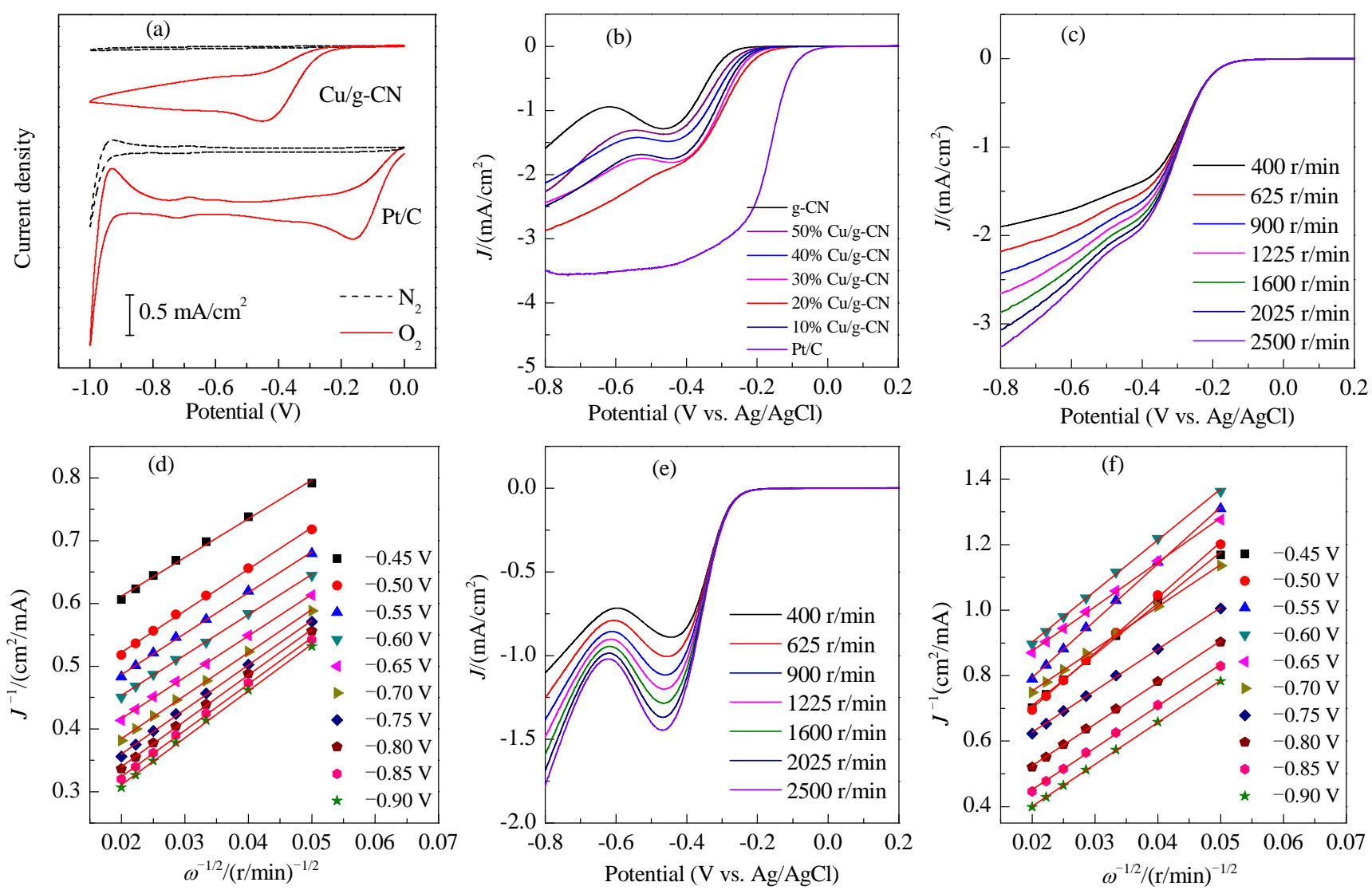

Fig. 2. (a) CVs for $\mathrm{Cu} / \mathrm{g}$-CN on a $\mathrm{RDE}$ in $\mathrm{N}_{2}$ or $\mathrm{O}_{2}$-saturated $\mathrm{KOH}$ solution ( $0.1 \mathrm{~mol} / \mathrm{L}$ ) with scan rate of $10 \mathrm{mV} / \mathrm{s}$; (b) Rotating-disk voltammograms of g-CN, Pt/C, Cu/g-CN with different mass ratios of $\mathrm{Cu}$, a sweep rate of $10 \mathrm{mV} / \mathrm{s}$ and rotation rate of $1600 \mathrm{r} / \mathrm{min}$; Rotating-disk voltammograms of (c) $\mathrm{Cu} / \mathrm{g}$-CN $(20 \mathrm{wt} \%)$ and $(\mathrm{e}) \mathrm{g}$-CN in $\mathrm{O}_{2}$-saturated $\mathrm{KOH}$ solution $(0.1 \mathrm{~mol} / \mathrm{L})$ with a sweep rate of $10 \mathrm{mV} / \mathrm{s}$ at the different rotation rates, and (d, f) the corresponding Koutecky-Levich plot of $J^{-1}$ versus $\omega^{-1 / 2}$ from -0.45 to $-0.9 \mathrm{~V}$, respectively.

The average size of the $\mathrm{Cu}$ nanoparticles was ca. $40 \mathrm{~nm}$. No agglomeration of the $\mathrm{Cu}$ nanoparticles on the g-CN surface may be due to that uncondensed functional groups can act as ligands to coordinate with $\mathrm{Cu}$ ions and then efficiently stabilize $\mathrm{Cu}$ nanoparticles.

The catalytic activity of $\mathrm{Cu} / \mathrm{g}-\mathrm{CN}(20 \mathrm{wt} \%)$ and $\mathrm{Pt} / \mathrm{C}$ towards the ORR was assessed by cyclic voltammetry (CV) in an $\mathrm{O}_{2}$ versus $\mathrm{N}_{2}$-staturated $\mathrm{KOH}$ solution $(0.1 \mathrm{~mol} / \mathrm{L})$ (Fig. 2(a)). For the $\mathrm{N}_{2}$-saturated solution, reduction peaks were negligible both for $\mathrm{Cu} / \mathrm{g}-\mathrm{CN}$ and $\mathrm{Pt} / \mathrm{C}$ electrode. For the $\mathrm{O}_{2}$-saturated solution, a remarkable reduction peak was observed with onset potential of ca. $-0.223 \mathrm{~V}$ (peak position at ca. $-0.443 \mathrm{~V}$ ) and $-0.04 \mathrm{~V}$ (peak position at -0.158 ) for $\mathrm{Pt} / \mathrm{C}$. To further reveal the ORR kinetics of g-CN and $\mathrm{Cu} / \mathrm{g}-\mathrm{CN}$, a RDE was used to investigate the electrocatalytic activity for the ORR by linear sweep voltammetry (LSV). For a fair comparison, the same amount of each electrocatalyst by mass loaded on the RDE, and the geometrical area of the electrode was used to calculated the current density [18,19]. Fig. 2(b) shows the corresponding LSV curves of $\mathrm{O}_{2}$ reduction at $\mathrm{g}-\mathrm{CN}, \mathrm{Pt} / \mathrm{C}$, and $\mathrm{Cu} / \mathrm{g}-\mathrm{CN}$ obtained with different masses of $\mathrm{Cu}$ in the composites in an $\mathrm{O}_{2}$-saturated $\mathrm{KOH}$ solution $(0.1 \mathrm{~mol} / \mathrm{L})$ at the same rotation rate $(1600 \mathrm{r} / \mathrm{min})$. In comparison with pristine $\mathrm{g}-\mathrm{CN}$, at which the oxygen reduction onset potential at around $-0.213 \mathrm{~V}$, all
$\mathrm{Cu} / \mathrm{g}-\mathrm{CN}$ showed superior ORR electrocatalytical activity. For instance, the $\mathrm{Cu} / \mathrm{g}-\mathrm{CN}$ (20 wt\%) exhibited a much more positive ORR onset potential $(-0.114 \mathrm{~V})$ and higher cathodic currents, demonstrating that a significant enhancement of ORR catalytic activity was achieved by the introduction of $\mathrm{Cu}$ species. Moreover, with the increase of $\mathrm{Cu}$ doping amount, the electrocatalytic activity of the $\mathrm{Cu} / \mathrm{g}-\mathrm{CN}$ ameliorated initially. The enhanced electrocatalytic activity may be contributed to the more activity sites and higher conductivity of composite with increase of the contents of $\mathrm{Cu}$. However, the electrocatalytic activity of $\mathrm{Cu} / \mathrm{g}$-CN did not improve, when the mass ratio of $\mathrm{Cu}$ in the composite surpasses $20 \mathrm{wt} \%$. This may be caused by the low content of nitrogen and poor dispersion of $\mathrm{Cu}$ nanoparticles, suggesting synergistic effect between $\mathrm{Cu}$ and g-CN is indispensable to the high ORR activity of the composite. Notably, the onset potential of $\mathrm{Cu} / \mathrm{g}-\mathrm{CN}$ (20 wt $\%$ ) was more negative than that of $\mathrm{Pt} / \mathrm{C}$, but the ORR current density at $-0.8 \mathrm{~V}$ of as-prepared $\mathrm{Cu} / \mathrm{g}-\mathrm{CN}$ was comparable with that of $\mathrm{Pt} / \mathrm{C}$.

The detailed voltammograms at different rotation rates for $\mathrm{Cu} / \mathrm{g}-\mathrm{CN}$ (20 wt\%) and g-CN are shown in Fig. 2(c) and (e), respectively. For the shortened diffusion layer, the measured current density () increased with increasing rotation rate $(\omega)$. Koutecky-Levich plots revealed good linearity between $J^{-1}$ and $\omega^{-1 / 2}$, and approximately constant slopes over the potentials 

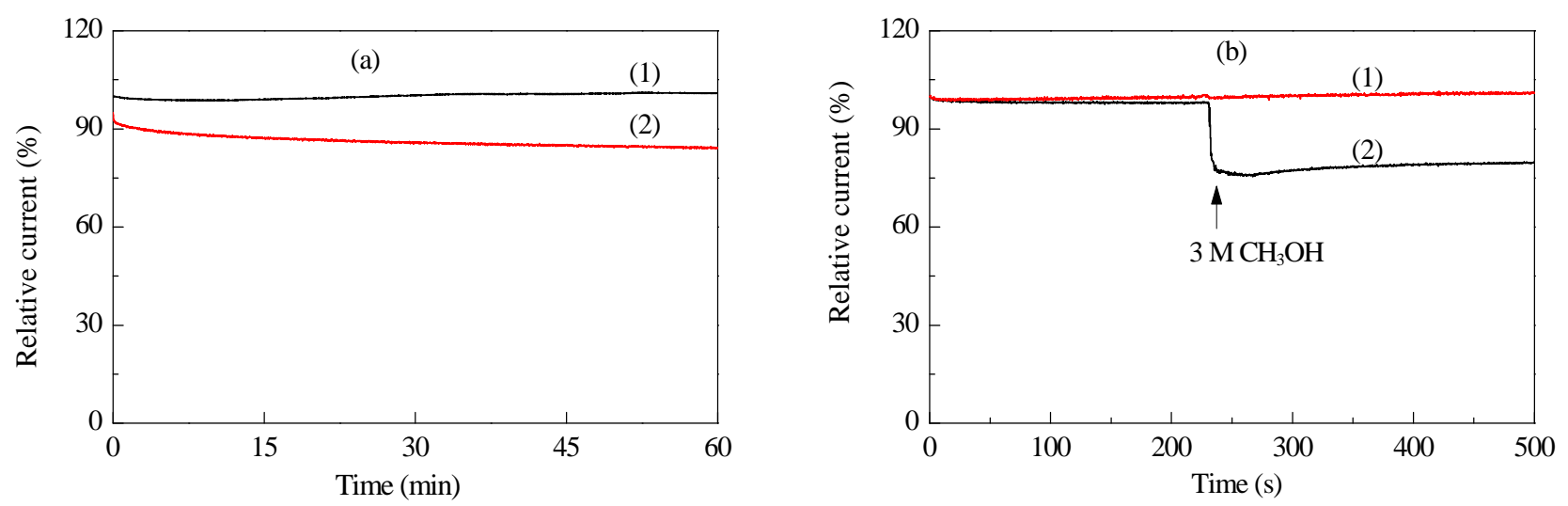

Fig. 3. (a) Chronoamperometry of $\mathrm{Cu} / \mathrm{g}-\mathrm{CN}(20 \mathrm{Wt} \%)(1)$ and $\mathrm{Pt} / \mathrm{C}$ (2) electrodes in $\mathrm{O}_{2}$-saturated $\mathrm{KOH}$ solution $(0.1 \mathrm{~mol} / \mathrm{L})$ at $-0.5 \mathrm{~V}$ for $60 \mathrm{~min}$ with the rotation rate of $1600 \mathrm{r} / \mathrm{min}$; (b) Chronoamperometric responses of $\mathrm{Cu} / \mathrm{g}-\mathrm{CN}(20 \mathrm{Wt} \%$ ) (1) and Pt/C (2) electrodes with $3 \mathrm{M}$ methanol added at $230 \mathrm{~s}$ with the rotation rate of $1600 \mathrm{r} / \mathrm{min}$.

from -0.45 to $-0.9 \mathrm{~V}$ were observed Fig. 2(d) and (f), respectively. The electron-transfer number $(n)$ and kinetic current density $\left(\mathrm{V}_{\mathrm{k}}\right)$ are the two important parameters that reflect the kinetics of the ORR process; these are calculated from the slope and the reciprocal of the intercept of the Koutecky-Levich plots, respectively. According to the Koutecky-Levich equations $[20,21]$, the calculated $n$ value of $\mathrm{Cu} / \mathrm{g}-\mathrm{CN}$ was 4.1 at $-0.7 \mathrm{~V}$; this indicates the oxygen reduction primarily dominated by a four-electron pathway. In contrast, the value of $n$ for g-CN at $-0.7 \mathrm{~V}$ was 2.2 , demonstrating that the oxygen reduction mainly followed a two-electron process with the formation of intermediate $\mathrm{HO}^{2-}$ ions. Moreover, the calculated kinetic current density of $\mathrm{Cu} / \mathrm{g}-\mathrm{CN}\left(\mathrm{J}_{\mathrm{k}}=4.09 \mathrm{~mA} / \mathrm{cm}^{2}\right)$ was higher than that of g-CN $\left.U_{\mathrm{k}}=2.02 \mathrm{~mA} / \mathrm{cm}^{2}\right)$. All these results suggest that doping $\mathrm{Cu}$ into the g-CN endows the materials with a superior electrocatalytic activity for ORR than that of the pristine g-CN.

The stability of $\mathrm{Cu} / \mathrm{g}-\mathrm{CN}(20 \mathrm{wt} \%)$ and $\mathrm{Pt} / \mathrm{C}$ catalysts in an $\mathrm{O}_{2}$-saturated $\mathrm{KOH}$ solution $(0.1 \mathrm{~mol} / \mathrm{L})$ was investigated by chronoamperometry at $-0.5 \mathrm{~V}$ with a $1600 \mathrm{r} / \mathrm{min}$ electrode rotation rate. After 3600 seconds, the commercial Pt/C catalysts exhibited a loss of $c a .15 \%$ of the specific catalytic activity, while the $\mathrm{Cu} / \mathrm{g}-\mathrm{CN}$ maintained stable throughout the experiment with only a $1 \%$ decrease in current density (Fig. 3(a)). In addition, $\mathrm{Cu} / \mathrm{g}-\mathrm{CN}$ had an excellent tolerance to methanol. As shown in Fig. 3(b), the addition of $3 \mathrm{M}$ methanol to the $\mathrm{O}_{2}$-saturated electrolyte did not apparently affect the catalytic activity of $\mathrm{Cu} / \mathrm{g}-\mathrm{CN}$ towards ORR. The curve of Pt/C catalyst displayed a dramatic decay of relative current. This result clearly shows that $\mathrm{Cu} / \mathrm{g}$ - $\mathrm{CN}$ selectively reduces $\mathrm{O}_{2}$, which is beneficial to avoid the occurrence of mixed potential in methanol fuel cells.

In summary, we report that a high efficient electrocatalyst $\mathrm{Cu} / \mathrm{g}$-CN for ORR was synthesized via a facile hydrothermal reaction using $\left(\mathrm{C}_{16} \mathrm{mim}\right)_{2} \mathrm{CuCl}_{4}$ and protonated g-CN. Meanwhile, the $\mathrm{Cu} / \mathrm{g}-\mathrm{CN}$ exhibited an impressive ORR catalytic activity with better long-term stability and higher selectivity than commercial Pt/C catalysts in alkaline electrolytes. Cooperating with $\mathrm{Cu}$ can significantly affect the electron transportation and active sites for oxygen reduction by electrochemical investigations. Thus, the rational combination of $\mathrm{Cu}$ and g-CN may offer a promising non-precious electrocatalyst for the ORR in fuel cells and other catalytic applications.

\section{Acknowledgments}

This work was partially supported under the Australian Research Council Discovery Project (DP150101717). The authors wish to acknowledge the Central Analytical Research Facility (CARF) at Queensland University of Technology for access to their facilities.

\section{References}

[1] M. K. Debe, Nature, 2012, 486, 43-51.

[2] J. Suntivich, H. A. Gasteiger, N. Yabuuchi, H. Nakanishi, J. B. Goodenough, Y. Shao-Horn, Nature Chem., 2011, 3, 546-550.

[3] J. T. Zhang, Z. H. Zhao, Z. H. Xia, L. M. Dai, Nature Nanotechnol, 2015, 10, 444-452.

[4] M. H. Shao, Q. W. Chang, J. P. Dodelet, R. Chenitz, Chem. Rev., 2016, $116,3594-3657$.

[5] L. M. Dai, Y. H. Xue, L. T. Qu, H. J. Choi, J. B. Baek, Chem. Rev., 2015, $115,4823-4892$.

[6] S. B. Yang, X. L. Feng, X. C. Wang, K. Müllen, Angew. Chem. Int. Ed., 2011, 50, 5339-5343.

[7] Y. F. Tang, B. L. Allen, D. R. Kauffman, A. Star, J. Am. Chem. Soc., 2009, 131, 13200-13201.

[8] J. Masa, W. Xia, M. Muhler, W. Schuhmann, Angew. Chem. Int. Ed., 2015, 54, 10102-10120.

[9] R. L. Liu, D. Q. Wu, X. L. Feng, K. Müllen, Angew. Chem. Int. Ed., 2010, 49, 2565-2569.

[10] D. S. Yu, Q. Zhang, L. M. Dai, J. Am. Chem. Soc., 2010, 132, 15127-15129.

[11] S. B. Yang, X. L. Feng, X. C. Wang, K. Müllen, Angew. Chem. Int. Ed., 2011, 50, 5339-5343.

[12] T. Ikeda, M. Boero, S. F. Huang, K. Terakura, M. Oshima, J. I. Ozaki, J. Phys. Chem. C, 2008, 112, 14706-14709.

[13] R. A. Sidik, A. B. Anderson, N. P. Subramanian, S. P. Kumaraguru, B. N. Popov, J. Phys. Chem. B, 2006, 110, 1787-1793.

[14] L. Xu, J. X. Xia, H. M. Li, H. N. Li, K. Wang, S. Yin, Eur. J. Inorg. Chem., 2011, 1361-1365. 


\title{
Graphical Abstract
}

Chin. J. Catal., 2017, 38: 1006-1010 doi: 10.1016/S1872-2067(17)62764-5

Cu nanoparticles supported on graphitic carbon nitride as an efficient electrocatalyst for oxygen reduction reaction

Henan Li, Yanan Xu, Hansinee Sitinamaluwa, Kimal Wasalathilake, Dilini Galpaya, Cheng Yan *

Queensland University of Technology, Australia; Jiangsu University, China

$\mathrm{Cu}$ supported on graphitic carbon nitride electrocatalyst was synthesized by a facile hydrothermal reaction and shows high catalytic activity for the oxygen reduction reaction in an alkaline electrolyte.

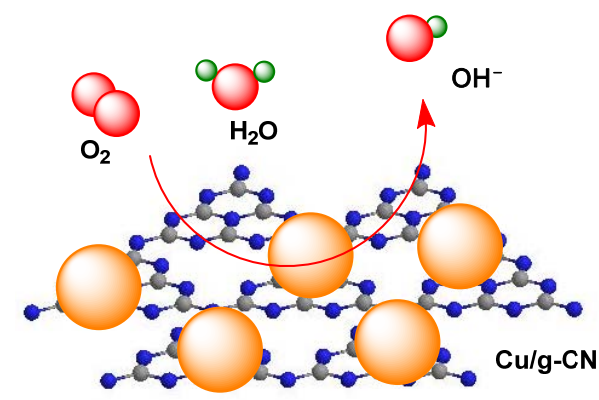

[15] L. Xu, H. N. Li, J. X. Xia, L. G. Wang, H. Xu, H. Y. Ji, H. M. Li, K. Y. Sun, Mater. Lett., 2014, 128, 349-353.

[16] J. Liang, Y. Zheng, J. Chen, J. Liu, D. Hulicova-Jurcakova, M. Jaroniec, S. Z. Qiao, Angew. Chem. Int. Ed., 2012, 51, 3892-3896.

[17] B. Jürgens, E. Irran, J. Senker, P. Kroll, H. Müller, W. Schnick, J. Am. Chem. Soc., 2003, 125, 10288-10300.

[18] G. Wu, K. L. More, C. M. Johnston, P. Zelenay, Science, 2011, 332,
443-447.

[19] R. L. Liu, D. Q. Wu, X. L. Feng, K. Müllen, Angew. Chem. Int. Ed., 2010, 49, 2565-2569.

[20] L. J. Yang, S. J. Jiang, Y. Zhao, L. Zhu, S. Chen, X. Z. Wang, Q. Wu, J. Ma, Y. W. Ma, Z. Hu, Angew. Chem. Int. Ed., 2011, 50, 7132-7135.

[21] D. S. Geng, Y. Chen, Y. G. Chen, Y. L. Li, R. Y. Li, X. L. Sun, S. Y. Ye, S. Knights, Energy Environ. Sci., 2011, 4, 760-764.

\section{石墨化氮化碳负载 $\mathrm{Cu}$ 纳米颗粒用作高效氧还原电催化剂}

\author{
李赫楠吕, 徐雅楠 ${ }^{\mathrm{a}}$, Hansinee Sitinamaluwa ${ }^{\mathrm{a}}$, Kimal Wasalathilake ${ }^{\mathrm{a}}$, Dilini Galpaya ${ }^{\mathrm{b}}$, \\ 间澄 ${ }^{\mathrm{a}, *}$ \\ a 昆士兰科技大学化学、物理与机械工程学院, 昆士兰布里斯班4001, 澳大利亚 \\ b 昆士兰科技大学中央分析研究室, 昆士兰布里斯班4001, 澳大利亚 \\ c江苏大学化学与化工学院, 江苏镇江 212013
}

摘要: 高活性低成本氧还原反应(ORR)电催化剂是燃料电池和金属/空气电池等可再生能源技术的关键组成部分. 在离子 液体 $\left[\left(\mathrm{C}_{16} \mathrm{mim}\right)_{2} \mathrm{CuCl}_{4}\right]$ 和质子化的石墨化氮化碳( $\left.\mathrm{g}-\mathrm{CN}\right)$ 的存在下, 采用简易的水热反应制备了 $\mathrm{Cu} / \mathrm{g}-\mathrm{CN}$ 电催化剂用于 $\mathrm{ORR}$. 与纯的g-CN相比, 所制 $\mathrm{Cu} / \mathrm{g}-\mathrm{CN}$ 表现出高的ORR催化活性: 起始电势正移 $99 \mathrm{mV}$, 为 2 倍动力学电流密度. 另外, $\mathrm{Cu} / \mathrm{g}-\mathrm{CN}$ 还 表现出比商用Pt/C (HiSPECTM 3000, 20\%)催化剂更好的稳定性和甲醇容忍性. 因此, 该催化剂作为廉价的高效ORR电催 化剂有望应用于燃料电池中.

关键词: 氧还原反应; 石墨化氮化碳; 纳米颗粒; 电催化剂; 离子液体

收稿日期: 2016-11-30. 接受日期: 2016-12-31. 出版日期: 2017-06-05.

*通讯联系人. 电话: +61-7-31386630; 电子信箱: c2.yan@qut.edu.au

基金来源：澳大利亚国家科研委员会探索项目(DP150101717).

本文的英文电子版由Elsevier出版社在ScienceDirect上出版(http://www.sciencedirect.com/science/journal/18722067). 